\title{
Power and portrayal
}

Lthough THE TwELfth century is often presented as a
'Golden Age' of English historical writing, few historians have
discussed the portrayal of twelfth-century women. An important exception, Marjorie Chibnall's study of women in Orderic Vitalis, is valuable for the way it explores Orderic's presentation of noblewomen according to their marital status, class and wealth. ${ }^{1}$ Essentially, Chibnall agreed with Eileen Power that the image of women in literature was complex and reflected the place of women in society generally. ${ }^{2}$ Power had warned of the need for careful treatment of the sources when she argued that women's theoretical position and their power in reality were contradictory. ${ }^{3}$ Lois Huneycutt has begun to uncover the increased attention paid to gender difference in the twelfth century, as well as stressing the paradoxical contrasts between the misogynistic language used to portray women and the practical realities of the complex societal expectations and responsibilities placed upon them. ${ }^{4}$ Pauline Stafford eschews a simple bi-polar 'image and reality' paradigm to place the emphasis on complex interactions of the political context of textual production, increasing attentions paid to critiques of wealth, power and gender definition in the twelfth century, and the origination of a new language to effect this. ${ }^{5}$ The roots of this new attention to the language which articulated queenly power, innovated in the writings of William of Malmesbury, lie in literature commissioned by royal female patrons in the specific political climate of late eleventh-century England. A key to Stafford's approach is the importance of the female life cycle in defining women's power and its interactions with social, familial and political connections and contexts. Public authority wielded by powerful women is discussed in masculine terms, since, as Duby and Stafford argue, power has the capacity to reor degender. ${ }^{6}$ This is explicable if we accept that male reaction to female 
power shows that it is historically often defined as illegitimate, unusual or unnatural. ${ }^{7}$

The following discussion draws on these key themes. It acknowledges the difficulties of analysing images of noblewomen in contradictory sources at a time when the historical discourse was evolving, owing to broader societal cultural shifts. ${ }^{8}$ Likewise the complex portrayals of noblewomen and the way that such images present particular views of noblewomen are set into an appreciation of the broader issues of authorial bias and political, social and cultural contexts. This analysis is above all concerned with the difficulty of measuring the power of noblewomen, given the complexities of the sources. ${ }^{9}$

Noblewomen appear in twelfth-century texts as both active subjects and passive objects, in complex ways, pursuing political ambition, as religious, pious wives, mothers and daughters. Such views of women depend very much on genre, date of composition and context of entry of a female character into the narrative. It is important to recognise that medieval writers wrote within convention. When Étienne de Fougères wrote his Le Livre des Manières in 1160-70, he described good and bad women, and used the countess of Hereford as his model of female courtly, aristocratic and 'good behaviour'. ${ }^{10}$ In the early twelfth century, Baudri de Bourgeuil wrote of the beauty of his subjects within a convention which dated from the poetry of Maximillian; therefore he wrote of eyes that shine like stars or teeth like ivory. ${ }^{11}$

Orderis Vitalis's view of women's power in the context of their political and warlike activity, like his view of men, is ambiguous, and by no means monolithic. ${ }^{12}$ For example, Orderic described women actively engaged in the military campaigns of their husbands. Isabel of Conches rode out to war 'armed as a knight among the knights, and she showed no less courage among the knights in hauberks than did the maid Camilla'. ${ }^{13}$ His story focuses on the disagreements between Helewise, the wife of William, count of Evreux, and Isabel of Conches, wife of Ralph of Tosny, who caused their husbands to take up arms against each other. Although the female warrior may well be no more than a 'well-worn literary motif', ${ }^{14}$ it is striking that Orderic ascribes different personal qualities to each woman. Isabel is praised as a generous, daring and gay character who was well loved. Her opponent Helewise is by contrast 'clever and persuasive, cruel and grasping'. He later commented on Isabel's retirement to a nunnery, where she 'worthily reformed her life' and repented of her 'mortal sin of luxury'. ${ }^{15}$ On the presence of women at the battle of Ascalon, he states that women remained off the battlefield with the noncombatants and that they are 'unwarlike by 
nature'. ${ }^{16}$ The emotional weakness of women is made gender-specific in Orderic's discussion of the expedition and aftermath of the defeat and capture of Mark Bohemond when campaigning against the Turks. He states that Tancred, the commander in chief, 'did not give way like a woman to vain tears and laments' but mustered an army and governed the lands. ${ }^{17}$ This assertion that women's emotional weakness affects their judgement is a recurring theme in twelfth-century chroniclers.

Powerful women who pursued their own political objectives in contexts that Orderic disapproved of, like their male counterparts, usually meet an ignominious end. The image of a powerful widow such as Adelais, the widow of Roger I count of Sicily, could be mutable. Orderic portrays her in a relatively sympathetic light when she ruled with counsellors for her son. However, he turns her into a murderous poisoner who, after marrying for a third time, is repudiated by her husband and dies 'an object of general contempt' and 'stained with many crimes'. Orderic approves a context for legitimate action which is thus as a widow in the stead of a legitimate heir. ${ }^{18}$ Aubrée, the wife of Ralph of Ivry, had built an 'almost impregnable castle'. ${ }^{19}$ Yet this achievement is tempered with the tale that she was killed by her own husband for attempting to expel him from it. ${ }^{20}$

Orderic's portrayal of such powerful women is complex. Mabel of Bellême is depicted as a cruel woman who deserved to meet a miserable end, murdered in her bed by a vassal whom she had deprived of his lands. Chibnall believes that the detail of a murder of a warrior in a bath lies within the epic tradition. ${ }^{21}$ Thus she implies that the story is a fabrication. The historicity of the detail is not as important here as the significance of the way in which Mabel's death is described. Orderic depicts Mabel using conventions of the epic genre; such a portrayal adds a certain dignity to her reputation whilst paradoxically seeking to destroy it, and thus he inverts the topos. In recompense for this Orderic records her obituary, as it was inscribed upon her tomb, but he states this was 'more through the partiality of friends than any just deserts of hers'. The obituary states that she gave good counsel, provided patronage and largesse, protected her patrimony, was intelligent, energetic in action and possessed honestas - honour, dignity. ${ }^{22}$ Orderic's sharp comment, however, is reflective of the nature of contemporary politics in early twelfth-century Normandy as much as of his distrust of women. The Bellême family were the hereditary enemies of the Giroie family, who were the founders of Orderic's monastery of St Evroul. ${ }^{23}$ Orderic's portrayal of Mabel of Bellême is therefore reflective of both contemporary clerical distrust of women in power and the nature of contemporary politics in Normandy. 
Orderic's attention to human frailty leads him to praise both men and women or condemn them for lapses in behaviour. Orderic records women's obituaries on several occasions, for example, Countess Sibyl, who allegedly died from poisoning, is praised for her birth, beauty, wealth, chastity, largesse and prudence. Women are usually praised for their beauty, fertility and religiosity: traits which Orderic admired in women. ${ }^{24}$ Other clerics in the twelfth century likewise wrote obituaries for women, including Baudri of Bourgeuil and Robert Partes, a monk, of Reading, who in the mid-twelfth century wrote nine obituaries for his mother which he sent to his twin brother. ${ }^{25}$

Orderic voices most approval for women who act within the context of religious patronage, and who are often depicted as acting with their sons and husbands to ensure the security of their gifts to his monastery. In this respect women are portrayed as having a beneficial influence. Avice, the daughter of Herbrand, who married Walter of Heugleville, is praised for her 'advice and wise counsel', her care for 'widows, waifs and the sick', as well as her beauty. She was 'most fair of face', 'well spoken and full of wisdom'; he praised her prudence and her 'golden tongue'. ${ }^{26}$ She acted as a civilising influence on her husband and 'restrained him from his earlier folly'. Indeed, Orderic copied her epitaph, which was composed for her by 'Vitalis the Englishman'. Her praiseworthy traits are her nobility, fair face, wisdom, modesty, sound morality, her fertility (she had twelve children 'most of whom died prematurely in infancy'), her generosity to the church, and her constancy and chastity. Stephen Jaeger believes that women played a civilising role in society, and that romance literature created chivalric values, values adapted from a social code of courtliness. ${ }^{27}$ Orderic thus apparently articulated the civilising influence of women upon their husbands prior to the emergence of romance literature. Indeed, this beneficial role of a wife in directing the morality of her husband is clear in Orderic's tale of a Breton whose wife persuaded him to give up a life of crime by obeying her wise counsels' ${ }^{28}$

Orderic's portrayal of women, laced with his perception of the appropriate behaviour of women at different stages of their life cycle, confirms the validity of Stafford's general approach. ${ }^{29}$ Thus a good wife encourages her husband in religious patronage, will offer advice and be obedient to her husband's wishes. A wife will give good counsel. Orderic's ambiguous view of women's influence extends to his view of sexual power. He describes how Adela, the wife of William duke of Poitou, used the marital bed to persuade her husband to go on crusade: 'between conjugal caresses' she urged him to go for the sake of Christendom, and to protect his honour. Orderic calls her mulier sagax et animosa. ${ }^{30}$ The

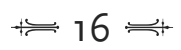


importance of the female life cycle underpins Orderic's portrayal of Windesmoth, the wife of Peter lord of Maule. She is praised for her modesty, chastity, piety, fecundity and her respect for her stepmother. He approves of the fact that she was young and newly married, since she was 'unformed' and thus more open to her husband's influence. Once widowed, she lived as a virtuous and 'happy matron', and remained chaste and unmarried for fifteen years, 'dutifully supported by her son in her husband's chamber up to old age! ${ }^{31}$ This theme of the obedient compliant wife and chaste widow is evident in the portrayal of Windesmoth's daughter-in-law. Her son Ansold, when on his deathbed, urged his wife, Odeline, to live chastely in widowhood, and to continue to guide their children morally until adulthood, and he implored her to release him from the marital bond so that he could become a monk. She 'wept copiously' and obediently consented to his wishes, since 'she had never been in the habit of opposing his will'. ${ }^{32}$ Orderic praises the obedience of women to their husband and sons, and approves of chastity in widowhood. The articulation of such values confirms the importance of the female life cycle and gender roles upon the portrayal of the power of wives and widows.

The vulnerability of women, and their dependence on their husband or kin, are a recurring theme in Orderic's history of the great Norman families. It also confirms that wives had important roles to play in lordship. For example, Radegund, the wife of Robert of Giroie, deputised for her husband whilst he was on campaign, but she lost control of the household knights when news of his death reached her. ${ }^{33}$ This example is suggestive of the vulnerability of wives to the vagaries of their husband's political fortunes, but also their supportive and martial roles. Such vulnerability is reflected in the exile of Agnes, daughter of Robert de Grandmesnil, after her husband, Robert of Giroie, had disregarded King Henry's will and attacked Enguerrand l'Oison. ${ }^{34}$ The difficult position of noblewomen because of contemporary political volatilities and the importance of familial connections is evident in the example of Matilda de L'Aigle. Orderic states that she shared her husband's bed 'fearfully, for three months only, amid the clash of arms' and 'for many years led an unhappy life in great distress' after the imprisonment of her husband. Her second marriage was no greater success: she was repudiated by her second husband, Nigel d'Aubigny, after the death of her brother. ${ }^{35}$ The impact that war and political misfortune could have on family members is often depicted. Orderic's story of the resolution of a dispute between Henry I and Eustace of Breteuil, a powerful Norman lord who had control of the strategic castle of Ivry, shows how women used kin networks 
to their advantage. ${ }^{36}$ Eustace was married to Juliana, an illegitimate daughter of Henry by a concubine. The marriage was of course a political alliance, but Orderic illuminates the difficulties this could cause women. Henry had control of Eustace's castle at Ivry, and agreed to return the castle at a later date. In order to show faith between Henry I and Eustace hostages were exchanged, but on malicious advice Eustace put out the eyes of the boy that he received. As a result Henry I handed over his two granddaughters to the father of the blinded boy, who then had them blinded and the tips of their noses cut off. ${ }^{37}$ This drove Eustace and Juliana to rebel. Juliana was sent to her husband's castle of Breteuil 'with the knights necessary to defend the fortress', whilst Eustace fortified his castles of Lire, Glos, Pont-Saint-Pierre and Pacy. Juliana's defence of the town of Breteuil was undone by the betrayal of the burgesses of the town. Henry besieged Juliana in the castle and, Orderic states, 'However, as Solomon says there is nothing so bad as a bad woman' - because she plotted to kill her father with a crossbow bolt, having requested a meeting with him. Her bolt missed and she was forced to surrender the castle to her father, who refused to let her leave with dignity. 'By the king's command she was forced to leap down from the walls' into the icy moat 'shamefully with bare buttocks'; Orderic calls her an 'unlucky amazon'. Her defeat and loss of the castle were not enough in Orderic's narrative. The historicity of the tale is less important than the fact that Orderic uses voyeuristic detail to portray her in a demeaning and humiliating way. Juliana was in a difficult political situation where conflicting family ties made her position as wife and daughter of protagonists difficult: her loyalty to her husband is, however, predominant. The allegation of her intention to commit patricide is indicative of Orderic's awareness of her pain, rage and anger at the mutilation of her children. ${ }^{38}$

The image of women supporting their husbands runs through many contemporary sources. Three key narrative sources, Orderic Vitalis, William of Newburgh and William of Malmesbury, confirm that powerful women played important roles in the decisive political campaigns of 1141. Orderic Vitalis states that Matilda countess of Chester and Hawise countess of Lincoln acted as decoys in a ruse by which earl Ranulf managed to capture Lincoln castle. ${ }^{39}$ They were 'laughing and talking with the wife of the knight who ought to have been defending the castle' when Ranulf went as though to escort his wife home. Ranulf overpowered the king's guards and seized the castle. This event was a turning point in the civil war and the catalyst of the further events which led to uneasy peace negotiations between the empress and King

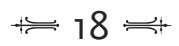


Stephen. William of Malmesbury in his Historia Novella likewise illustrates the role of wives in supporting their husbands in 1141. He shows that after the battle of Lincoln, which resulted in the capture of Earl Robert of Gloucester and King Stephen, Earl Robert knew he that he could rely on his wife, the countess Mabel, to support his political strategy. When cajoled and then threatened by Stephen's supporters to abandon the empress, he remained steadfast in his opposition, able to do so since he knew that his wife would send Stephen to Ireland should anything happen to him. ${ }^{40}$ William of Malmesbury also shows Mabel's concern at the capture and imprisonment of her husband. He states that she was willing to accept a proposal detailing the exchange of the earl for less than his true ransom value, driven as she was by 'a wife's affection too eager for his release'. Malmesbury then adds that Robert earl of Gloucester 'with deeper judgement refused [the offer]'. Malmesbury is careful to stress Mabel's reliance on her husband's decisions even when he was imprisoned. Mabel's political judgement is thus portrayed as affected by her emotions and weaker than that of her husband. Countess Mabel was an important linchpin in continuing the political strategy of the Angevin cause whilst Earl Robert was imprisoned, having a central role in securing the release of Earl Robert. John of Worcester portrays both the countess Mabel and Stephen's queen Matilda as proactively involved in the negotiating process. Both the queen and Mabel are portrayed as supporting their husbands, negotiating with each other through messengers. It is striking that there is no disparaging comment, only recognition of their actions as peacemakers, and indeed power brokers, involved in careful diplomacy. ${ }^{41}$

Later in the twelfth century Petronella countess of Leicester was also involved in the military campaigns of her husband. ${ }^{42}$ The main subject of Jordan Fantosme's Chronique de la Guerre entre les Anglois et les Ecossois is the war between the Scots and the English in 1173-74, and the rebellion of the earl of Leicester. Fantosme wrote to entertain in a classical tradition, to give moral instruction and to show that human folly was subject to divine law. ${ }^{43}$ This purpose only partially accounts for a story about the martial exploits of Petronella countess of Leicester. Fantosme also wrote for an aristocratic audience who would be able to identify with the story, its content and moral code. Fantosme describes the deliberations of the earl's council of war prior to the battle of Fornham on 16 October 1173, at which the earl and the countess were both captured. To the earl's plea 'Ah God!... Who will advise me to make a start of this business?' Petronella replies, 'I will, my lord.' Petronella gives her husband counsel, a classic literary topos. Fantosme 
portrays how a powerful countess would argue her case through the use of classic literary conventions. Petronella urges her husband on and incites the council of Flemings, French and Picards with the words 'The English are great boasters, but poor fighters; they are better at quaffing great tankards and guzzling'. Ian Short considers this gibe as a humorous literary effect, since such anti-English sentiments were 'common currency' in twelfth-century literature. ${ }^{44}$ Petronella was herself the daughter of a Continental magnate - would such gibes be nothing more than a joke in this context? Is the literary joke a double bluff? Petronella stresses the marriage connection between her husband and the earl of Gloucester, and maintains that their connection as brothers-in-law meant that the earl of Gloucester would not fight. ${ }^{45}$ Jordan states that the earl had his wife dressed in armour and gave her a shield and lance. Jordan, with a knowing aside, tells the audience that the earl has made an error in arming his wife that will cost him dear: 'his lunacy will have a hard life'. During the battle Petronella fled the scene of battle, fell into a ditch and, having nearly drowned, lost her rings. In despair at the tide of battle turning against her and her husband, she was dissuaded from suicide by the actions of a knight who rescued her from a ditch and told her, 'My lady, come away from this place and abandon your design! War is all a question of losing and winning. ${ }^{346}$

The portrayal of Petronella in a dramatic scene and her reported speech given at the council are illuminating. Her advice is poor, since the battle that she urges, however persuasively, leads to the defeat of her and her husband. The inclusion of the detail that she lost her rings in the fosse adds to her humiliation and mirrors her loss of dignity. The portrayal of Petronella is couched within specific literary topoi of the counsel she gave and her martial exploits which end in defeat. Fantosme articulates a traditional distrust of women giving counsel, their involvement in military affairs and of their power to effect change. He thus portrays Petronella in an unsympathetic way.

Other sources, however, give a different view of Petronella. Charters, for example, show that she was influential in similar ways to other powerful women in the twelfth century. She was a patron of religious houses in both England and Normandy with her husband. She witnessed his charters. Further she granted her own charters to St Evroult and St Mary's, Lire, held her own court and had her own seal. ${ }^{47}$ Four of the major narrative sources for the events of Henry II's reign which describe the events of 1173-74 relate the events of the earl of Leicester's rebellion and note that Petronella was captured with her husband following the battle of Fornham. ${ }^{48}$ Of these, three note the capture of 
Earl Robert and Petronella without comment. William of Newburgh, however, states, Captusque est comes cum conjuge, virilis animae femina, and gives the further details that Petronella was on campaign with Earl Robert and landed with him at Wareham at the start of the rebellion. ${ }^{49}$ His comment that Petronella was a woman with a 'man's spirit' describes her in male-gendered terms, evoking Duby and Stafford's contention that the exercise of power could de- or re-gender individuals. ${ }^{50}$ Newburgh's view is expressive of the contradictions within sources which show how political women's image was coloured by clerical misogyny. This contrasts with Jordan Fantosme's portrayal, which, despite the depiction of the ultimate humiliation and defeat of Petronella, nevertheless shows her eloquent counsel which enables her to influence action and consequence. Matthew Paris, discussing these events in his thirteenthcentury Historia Anglorum, states that Petronella threw her ring into the flowing stream indignantly, since she was unwilling to let her enemies have her ring, which was set with a precious gem. This is a more positive portrayal. Petronella, despite defeat, threw her rings away with indignation, suggesting that she somehow kept her poise and deprived her enemies of their spoils. ${ }^{51}$ This story also appears in his earlier but lengthier Chronica Majora, ${ }^{52}$ but the phrase prae indignatione is a later addition to his text which adds spice to the story. The discrepancy between the image of Petronella in literary sources and the impression of an important lay religious benefactor evidenced by charters confirms that Stafford's general approach to the study of royal women is applicable to an analysis of noblewomen, namely that the portrayal of royal women was mutable and dependant on a variety of interlocking factors, including political context, genre of text, clerical misogyny, as well as the vagaries of the female life cycle. ${ }^{53}$ Certainly, although the image of Petronella is intriguing in literary sources, such sources alone do little justice to the ways that Petronella exerted power and influence; for that story we must turn to her charters, which illustrate her role in secular lordship. ${ }^{54}$

Just as Orderic Vitalis and Jordan Fantosme portrayed women's participation in the military campaigns of their husbands, so too the effect that war or rebellion could have on the political position of noble and aristocratic wives and widows is evident in other sources such as MS D of the Anglo-Saxon Chronicle and in sources dependent upon it, such as John of Worcester. For example, Queen Edith was sent to Chester by her brothers Earls Edwin and Morcar in 1066, although, as Stafford has argued, Edith's actions in 1066 are a mystery. Indeed, the image of Edith in the Anglo-Saxon Chronicle needs some refinement, since Edith survived her loss of status and lived in retirement on 
considerable resources. ${ }^{55}$ Some women of the nobility may have taken a more direct role in the organisation of resistance to the Normans. Indeed, the countess Gytha may have been central to the English resistance and important in the refusal of the Godwin family to accept the defeat at Hastings as final. She was the focus of resistance at Exeter, and fled only after she was besieged. ${ }^{56}$ When she fled from England in 1067, on her way to Saint-Omer, she left via the Isle of Flatholm 'and the wives of many good men accompanied her. ${ }^{57}$ She was thus given a tragically noble role and had the potential to became a symbol of English resistance to the Norman invaders. ${ }^{58}$ In the revolt of the three earls of 1075, the wife of Ralph earl of Norfolk and Suffolk held her husband's castle at Norwich whilst he fled for Brittany when he realised his cause was lost. She held out in the besieged castle for some time, and left only once she had made terms with William the Conqueror. She was allowed to leave England: her husband was later imprisoned. ${ }^{59}$ Given that such events were often organised by women, the arrangement of the details of the wedding feast may well have been the responsibility of his wife and as such it is likely that she knew about the conspiracy that was hatched. ${ }^{60} \mathrm{~A}$ recurrent theme in twelfth-century chronicles is the way that noblewomen's fortunes were directly linked with those of their male kin: when Baldwin de Redvers refused to accept King Stephen, he and his wife and children were disinherited and exiled. ${ }^{61}$

However, it was not only aristocratic or royal women who could seize the opportunity to exert power and influence. Nichola de la Haye was one such woman from below the ranks of the titled aristocracy who was more than capable of directing and managing her own affairs. Nichola was the daughter and co-heiress of Richard de la Haye, the hereditary constable of Lincoln castle and sheriff of Lincolnshire, and passed the office of constable to each of her husbands. ${ }^{62}$ In 1191 after her husband, Gerard de Camville, quarrelled with William Longchamp, the Chancellor and Justiciar of England, she was besieged at Lincoln Castle. Richard of Devizes tells us that her husband was with Count John, and once besieged 'Nicholaa, whose heart was not that of a woman, defended the castle manfully. ${ }^{63}$ She enjoyed a cordial relationship with John, and stoutly defended Lincoln when it was besieged by rebels under Louis of France. Having survived two sieges, the aged Nichola determinedly resisted attempts by the husband of her granddaughter, William, the son of the earl of Salisbury, to eject her from it. ${ }^{64}$ Nichola's actions received different interpretations in different sources. Devizes gave her qualities associated with male action, whilst Wendover praised her tenacity in holding the castle in 1217. Indeed, Nichola's defence of 
Lincoln in 1217 was a significant factor in turning the tide of events in favour of King John. According to a later tradition recorded at the local shire court, after the death of Gerard de Camville in 1215 Nichola left the castle and went to meet John with its keys in her hand to argue that she was too old to defend it. John replied to his 'beloved Nichola' that she should keep the castle until he ordered otherwise. ${ }^{65}$ The Histoire de la Guillame le Maréchal, written about 1226, shows that Nichola's defence of Lincoln facilitated the penetration of Lincoln by Peter des Roches bishop of Winchester before the final battle which ended the siege. He entered the castle by a secret entrance and met Nichola, a 'noble lady to whom the castle belonged and was defending it as best she could'. She was apparently delighted to see the bishop, who reassured her that the siege would soon be over. ${ }^{66}$ It is interesting that the author of the Histoire accepted Nichola's role without comment: she was 'noble' and defended as 'best she could'. It is also apparent that Nichola's actions as a wife received a different interpretation from those as an elderly widow; the female life cycle affected how she was portrayed. On the other hand, the same actions might receive different interpretations because of their immediate political significance: Devizes was hostile because her actions in 1191 placed her in opposition to Richard I, and in his case gender stereotyping served as a tool with which to attack her.

Just as we saw in the portrayal of Mabel of Bellême by Orderic Vitalis, the portrayal of women could have a propagandist political edge. For example, John of Worcester eulogises Queen Margaret, praising her in the familiar stereotypical way, lauding her piety, charity and generosity ${ }^{67}$ By contrast the death of William's queen, Matilda, is only tersely noted. The Worcester Chronicle, which drew on the Anglo Saxon Chron$i c l e$ and other sources such as Bede, for its view of events prior to $1121,{ }^{68}$ was completed c. 1140. Like MS D of the Anglo-Saxon Chronicle it is laced with a pro-English bias, ${ }^{69}$ and the view of Margaret is related to the image of her then current in northern England in the context of the succession dispute. ${ }^{70}$ Thus her inscription as a tool of propaganda explains the fulsome praise of Queen Margaret. It is possible that Matilda countess of Boulogne attempted to get both of her blood lines sanctified in support of the political ambitions of her husband. It has traditionally been argued that her daughter Matilda, as queen of England, united the bloodlines of the old English royal house with that of the Normans. She also carried Scottish royal blood in her veins. The Vita of Queen Margaret commissioned by her daughter had a political intent as much as a stereotypical format. Duby finds a similar political propagandist context to explain the production of the Vita of Ida countess of Boulogne, 
which praised Ida for her fertility and was commissioned by her granddaughter, Matilda, who was also a granddaughter of Queen Margaret. Duby alleges that the monks of Vasconviliers wrote the Vita when the count of Boulogne felt he had a claim to the English throne. ${ }^{71}$ Whether or not this is a realistic appreciation of contemporary political circumstances, it is significant that both Duby and Stafford acknowledge that the portrayal of powerful women could be propagandist. Stafford's contention that twelfth-century writers found a new language in which to articulate queenly political power ${ }^{72}$ is a paradigm applicable to the ways that Orderic Vitalis, William of Newburgh and John of Worcester portrayed political women who were not queens, since the wives of powerful political men were portrayed as able political agents. Significantly, however, where women enter the political narrative roles are presented in a gendered way. Thus the countess Mabel had weaker political judgement than her husband; the countesses of Chester and Lincoln, whilst involved the military campaign of their husbands, were laughing and gossiping whilst Earl Ranulf took the castle. Richard of Devizes, writing at the end of the twelfth century, could describe powerful women only in gendered terms; Nichola de la Haye defended her husband's castle 'manfully'; Hawise countess of Aumâle was a 'woman who was almost a man, lacking nothing except the virile organs'. ${ }^{73}$ The qualities Devizes admires in a woman are those of Queen Eleanor, who was beautiful and virtuous, powerful yet gentle, humble yet keen-witted, qualities 'which are rarely to be found in a woman'. ${ }^{74}$

As Stafford has shown, misogyny leads writers to articulate the political power of royal women by recourse to categories of gender, and the image of wives and widows could differ owing to the impact of the female life cycle. ${ }^{75}$ Such an analytical framework is applicable to the study of twelfth-century women of the nobility, and the complexity of the image of noblewomen confirms that an image and reality paradigm is inadequate as a conceptual tool to decode women's power. Thus, for example, that Countess Mabel was portrayed as weaker in spirit than her husband Earl Robert of Gloucester, but nevertheless able to assume the reins of power when appropriate, confirms the importance of the female life cycle and thus marital status to women's power. As the discussion of Orderic Vitalis shows, the portrayal of powerful twelfthcentury women was complex and is reflective of more than authorial political and cultural biases. Noblewomen were praised in stereotypical ways and their given attributes reveal the way that contemporary authors viewed noblewomen: their beauty, fertility, religious benefaction and fulfilment of dutiful family roles as wives, widows and daughters. The 
role of countesses such as Mabel of Gloucester or Petronella of Leicester received different interpretations in different sources, and this is suggestive of the complex ways that contemporary writers viewed women. The portrayal of Petronella had a hard political contemporary edge to it. As such noblewomen fared no better or worse than their male counterparts in that historical writing in any period is a political act. Yet women such as these faced a further category of analysis: that of their gender. Although noblewomen were expected to take action, and did, in appropriate contexts their roles were subject to hostile scrutiny based on ideas about gender roles. Nevertheless the ways individual women such as Countess Mabel of Gloucester, or Nichola de la Haye, are portrayed have much to tell us about the language of power and gender, as well as the way that they seized opportunities to affect political events and, in short, acted as powerful individuals at the heart of the power structures of the aristocratic and noble élite of the twelfth century.

\section{Notes}

1 M. Chibnall, 'Women in Orderic Vitalis', Haskins Society Journal, 2 (1990), 105-21.

2 It must be admitted, however, that a minority of writers continued to portray women in the most limited terms, in essence as simple pawns in the politics of aristocratic marriage (e.g. the Hexham historians: 'The chronicle of John, prior of Hexham, from A.D. 1130 to A.D. 1154' and 'The acts of King Stephen, and the battle of the Standard, by Richard, prior of Hexham, from A.D. 1135 to A.D. 1139', in The Church Historians of England, ed. Joseph Stevenson (5 vols, London: Seeley, 1853-58), IV (i) (1856), pp. 1-32, 33-58 respectively).

3 E. Power, 'The position of women', in C. G. Crump and E. F. Jacob (eds), The Legacy of the Middle Ages (Oxford: Clarendon Press, 1926), pp. 410-33; cf. E. Power, Medieval Women, ed. M. Postan (Cambridge: Cambridge University Press, 1975).

4 L. Huneycutt, 'Female succession and the language of power in the writings of twelfth-century churchmen', in Parsons (ed.), Medieval Queenship, pp. 189-201. Cf. J. Weiss, 'The power and weakness of women in Anglo-Norman romance', in C. M. Meale (ed.), Women and Literature in Britain, 1150-1500 (Cambridge: Cambridge University Press, 1993), pp. 7-23, who asserts an outdated belief in decline in the social and economic position of women in England following the Norman Conquest, epitomised by D. M. Stenton's The English Woman in History (London: Allen \& Unwin, 1957), and dismissed by Stafford ('Women and the Norman Conquest', pp. 221-49).

5 P. Stafford, 'The portrayal of royal women in England, mid-tenth to mid-twelfth centuries', in Parsons (ed.), Medieval Queenship, pp. 143-67, esp. pp. 157-61.

6 Stafford, 'Emma', p. 14; Duby, 'Women and power', p. 78.

7 S. Dixon, 'Conclusion - the enduring theme: domineering dowagers and scheming concubines', in B. Garlick and others (eds), Stereotypes of Women in Power: Historical Perspectives and Revisionist Views (New York and London: Greenwood Press,

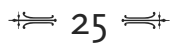


1992), pp. 210-11. Such categorisations of women and power had tenacious roots, as Janet Nelson has convincingly shown in her study of ninth-century Francia: 'Women at the court of Charlemagne', pp. 49-50.

8 Huneycutt, 'Female succession', p. 191.

9 It is necessarily selective in its choice of sources because the exemplification of central themes is its goal, rather than a detailed analysis of the image of women in all twelfth-century literary sources. One necessary omission, therefore, is the satirical work of Walter Map. The genre in which he worked, unlike those of the other authors treated here, tended to limit him to presentations of the most extreme gendered stereotypes of women, without the need to accommodate their involvement in lordship and politics. For example, we have extreme cases of sexual incontinence by nuns, the abject submission of a loyal wife, and the use of sexual insults in a stereotyped attack on a nobleman's wife: Walter Map, De Nugis Curialium: Courtiers' Trifles, ed. M. R. James, revised by C. N. L. Brooke and R. A. B. Mynors (Oxford: Clarendon Press, 1983), pp. 419, 444, 447-8. Thus the discussion is limited by reference to the major narrative sources, including Orderic Vitalis, William of Malmesbury and William of Newburgh, to discuss specific themes or case studies.

10 Étienne de Fougères, Le Livre des Manières, ed. R. A. Lodge, Textes Littéraires Français (Geneva: Droz, 1979), verses 302-8, 100-1. The countess of Hereford could either be Cecily countess of Hereford, the daughter of Sibyl de Neufmarché and Roger earl of Hereford (married three times, to Roger earl of Hereford (d. 1155), William de Poitou (d. 1162) and Walter de Mayenne (d. 1190/91): CP, 6, pp. 455-7); or possibly Margaret de Bohun, the daughter and eventual co-heiress of Miles earl of Hereford, who married Humphrey de Bohun (ibid., pp. 457-8 and note e).

11 J. Verdun, 'Les sources de l'histoire de la femme en Occident au X-XIII siècles', Cahiers de Civilisation Médiévale, XX (1977), 219-50. For a more detailed treatment of Baudri of Bourgeuil see Chapter 3 below.

12 Chibnall argued that Orderic described how women exerted power despite their theoretical subordination: 'Women in Orderic Vitalis', pp. 108-9, 116. Huneycutt, however, began to consider gender issues and demonstrated that women were more likely to fall prey to extremes of virtue and evil and that female wickedness was 'often used as an explanatory device': 'Female succession', pp. 192-3.

$13 \mathrm{OV}, 4.212-14$.

14 Nelson, 'Gender and genre', p. 150.

15 OV, 3. 128-9.

16 OV, 5. 178.

$17 \mathrm{OV}, 5 \cdot 354-5$.

$18 \mathrm{OV}, 6.366-7$; OV, 6. $428-33$. She is accused of poisoning her son-in-law. Poisoning is an allegation levelled at women in Orderic. See OV, 4. 181, where he alleges that the wife of Robert Guiscard attempted to poison her stepson.

19 OV, 4. 290-1.

20 Charter evidence corroborates Orderic's example of a powerful woman who had control of a castle. In 1075 Queen Matilda was present when Countess Adeliza (of Burgundy), who had bought the castle of Le Homme from her brother, granted it to the abbey of La Trinité, Caen: Regesta Regum Anglo-Normannorum: The Acta of

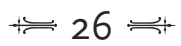


William I, 1066-1087, ed. D. Bates (Oxford and New York: Clarendon Press, 1998), no. 58 .

23 K. H. Thompson, 'Orderic Vitalis and Robert of Bellême', JMH, 20 (1994), 133-41.

24 OV , 6. 38-9. See also the obituary of Avice, daughter of Herbrand, discussed in the following paragraph. This is a recurring theme; see, for example, Margaret, the wife of Geoffrey of Mortain, OV, 2. 446-7.

25 W. H. Cornog, 'The poems of Robert Partes', Speculum, 12 (1937), 215-50. The obituaries occur at pp. 240-3, from BL, MS Egerton 2951. For Baudri, see below, pp. 33-4. For epitaphs, see E. M. C. van Houts, 'Latin Poetry and the Anglo-Norman court 1066-1135: The carmen de Hastingae proelio', JMH, 15 (1989), 40-3, 45-6.

OV, 3. 256-9. Her husband was buried 'at the feet of his wife'; for his obituary see OV, 3. 258-9.

27 C. S. Jaeger, The Origins of Courtliness: Civilizing Trends and the Formation of Courtly Ideals, 939-1210 (Philadelphia: University of Pennsylvania Press, 1985), p. 209. OV, 3. 342-3.

29 Stafford, 'Portrayal of royal women', pp. 144-5.

30 OV, 5. 324-5.

$31 \mathrm{OV}, 3.180-1$. A bad wife is one who is 'foolish and nagging', who gives bad counsel - as in the example of Emma, the wife of Richard of La Ferté-Frênel, who encouraged her husband to rebel: OV, 4. 218-19. A bad wife can be conveniently blamed for poor policies.

32 OV, 3. 194-7.

33 OV, 4. 292-5.

34 OV, 3. 134-5.

$35 \mathrm{OV}, 4.282-4$.

36 OV, 6. 210-15.

37 Orderic states, 'So innocent childhood alas! suffered for the sins of the fathers': OV, 4. 212-13. Facial disfigurement was the punishment in the later Middle Ages for adultery or prostitution.

38 OV , 6. 212-13: Orderic states that both parents' feelings were 'roused by the suffering and maiming of their offspring ... [and they were] in great distress'.

39 OV, 6. 538-41.

40 William of Malmesbury, Historia Novella, ed. K. R. Potter (London and New York: Nelson, 1955), pp. 67-8.

41 The Chronicle of John of Worcester, ed. R. R. Darlington and P. McGurk (3 vols, Oxford: Clarendon Press, 1995- ), 3. 302-5. Charter evidence shows that Mabel was important in the administrative affairs on the honour of Gloucester beyond crisis intervention in 1141 and was, significantly, responsible for the administration of Gloucester lands in Normandy for her son later in the twelfth century: pp. 94-5 below.

42 A. Gransden, Historical Writing in England c. 550 to c. 1307 (London: Routledge, 1974), p. 237; M. D. Legge, Anglo-Norman Literature and its Background (Oxford: Clarendon Press, 1963), p. 75, gives the date of composition as 1174-75 and 1170-75 respectively. 
Jordan Fantosme's Chronicle, ed. R. C. Johnstone (Oxford: Clarendon Press, 1981), p. xvi.; Legge, Anglo-Norman Literature, p. 75; Gransden, Historical Writing, p. 236.

44 Short, 'Tam Angli quam Franci', p. 153.

45 Fantosme's Chronicle, pp. 72, 73, lines 974-83.

46 Ibid., pp. 78-9, lines 1064-71.

47 For example, she gave lands to St Évroul: Cartulary St Evroult, BN, MS Latin 11055, ff. $33 \mathrm{v}-35 \mathrm{r}$ (thirteenth-century); PRO, 31/8/14oB, pt 1 (Cartulaire de la BasseNormandie) 300, copy of $c .1835$ by Léchaude d'Anisy; CDF, 228; VCH Leicester, 2.23 (DBC); she confirmed lands to Nuneaton Priory, which her daughter Hawise entered, Danelaw Charters, no. 322, and gave a charter respecting tithes in the church of Netheravon, Sarum Charters, no. 62. For her role as a witness and grantor to St Mary's Evreux, Fontaine, St Mary's de Sainte Barbe and St André-en-Gouffern see $C D F$, nos 306, 139, 199, 211. For her seal, see a description in Danelaw Charters, no. 322, and Book of Seals, no. 5, Appendix One, no. 73.

48 Roger of Howden, Chronica Rogeri de Hoveden, ed. W. Stubbs (4 vols, RS, 51, 186871), pp. 2. 55; Gesta Regis Henrici Secundi Benedicti Abbatis: The Chronicle of the Reigns of Henry II, and Richard I, AD. 1169-1192, Known commonly under the Name of Benedict of Peterborough, ed. W. Stubbs (2 vols, RS, 49, 1867), 1. 62; William of Newburgh, 'Historia Rerum Anglicarum', ed. R. Howlett, in Chronicles of the Reigns of Stephen, Henry II and Richard I (4 vols, RS, 82, 1884), 1. 179; Gervase of Canterbury, The Historical Works of Gervase of Canterbury: The Chronicles of the Reigns of Stephen, Henry II., and Richard I., by Gervase, the Monk of Canterbury, ed. W. Stubbs (2 vols, RS, 73, 1879-80), 1. 246.

49 William of Newburgh, Historia Rerum Anglicarum, p. 246.

50 Stafford, 'Emma', p. 14; Duby, 'Women and power', p. 78.

51 Matthew Paris, Historia Anglorum, ed. F. Madden (3 vols, RS, 44, 1866-69), 1. 381: Comitissa vero superba nimis, annulem habens in digito cum gemma pretioissima, in amnen prope fluentum prae indignatione projecit, nolens hostibus de sua captione tantum habere proventum.

52 Matthew Paris, Chronica Majora, ed. H. R. Luard (7 vols, RS, 57, 1872-83) 2. 290.

53 Stafford, 'Portrayal of royal women', pp. 146-9.

54 The charters are discussed below, pp. 69-70.

55 Chronicle of John of Worcester, 2. 604-5; Stafford, Emma and Edith, pp. 274-5.

56 M. T. Flanagan, Irish Society, Anglo-Norman Settlers, Angevin Kingship: Interactions in Ireland in the late Twelfth Century (Oxford: Clarendon Press, 1989), p. 59.

57 ASC, MS D 1067.

58 Stafford, Emma and Edith, p. 277.

59 ASC, MS D 1076 [1075].

60 For prominent examples of women sponsoring marriages and their celebration see Adela of Blois's 'generous provision' for a marriage which 'was celebrated magnificently': OV, 3. 182. See also The Letters of John of Salisbury, ed. W. J. Millor, H. E. Butler and C. N. L. Brooke (2 vols, vol. 1: London: Nelson, 1955; vol. 2: Oxford: Clarendon Press, 1979), p. 2, no. 144, where in a letter of John of Salisbury of January 1165 , he states that the wife of Robert count of Dreux sent a present of 300 ells of cloth to Henry II in the hope that he would arrange favourable marriages for her children. 
61 Chronicle of John of Worcester, pp. 218-19.

$62 H K F, 3.56$; for further discussion of Nichola, see pp. 160-1.

63 Girardus erat cum comite, et uxor eius Nicolaa, nichil femineum cogitans, castellum uirilter custodiebat: Richard of Devizes, The Chronicle of Richard of Devizes of the Time of King Richard the First, ed. J. T. Appleby (London and New York: Nelson, 1963), pp. 30-1.

64 C. Hill, Medieval Lincoln (Cambridge: Cambridge University Press, 1948), p. 199.

65 Rotuli Hundredorum temp. Hen. III. \& Edw. I. in Turr' Lond. et in Curia Receptae Scaccarii Westm. asservati, ed. W. Illingworth (2 vols, London: Record Commission, 1812-18), 1. 309.

66 Histoire de la Guillaime le Maréchal, ed. and trans. P. Meyer, in English Historical Documents, III, 1189-1327, ed. H. Rothwell (London: Eyre \& Spottiswoode, 1975), pp. 88-9.

67 Chronicle of John of Worcester, pp. 66-7; for Margaret see p. 31. Her seal, Appendix 1, no. 20.

68 Gransden, Historical Writing, p. 146.

69 Ibid., p. 147. For the image of Queen Margaret see L. Huneycutt, 'The idea of a perfect princess: the Life of Saint Margaret in the reign of Matilda II (1100-18)', ANS, 12 (1990 for 1989), 81-97. Her meaning as a saint: R. Folz, Les Saintes reines de Moyen Âge en Occident (VIe-XIIIe siècles) (Brussels: Société des Bollandistes, 1992), p. 94, who notes that her husband King Malcolm is portrayed as a crude warrior. See OV, 4. $270-5$, where she is praised for her piety and her preparations for death.

70 Stafford, 'Portrayal of royal women', p. 154.

71 G. Duby, 'The matron and the mis-married woman: perceptions of marriage in northern France circa 110o', in T. H. Aston, P. R. Coss, C. Dyer and J. Thirsk (eds), Social Relations and Ideas: Essays in Honour of R. H. Hilton (Cambridge: Cambridge University Press, 1983), pp. 95-9.

72 Stafford, 'Portrayal of royal women', p. 161.

73 Richard of Devizes, pp. 10, 31. This was a private view written for a friend.

74 Ibid., p. 25.

75 Stafford, 'Portrayal of royal women', p. 148. 